\title{
Mersin-Gözne Yaylası'nda Istar Dokumacılığı ve Örnekleri
}

\author{
Istar Weaving and Some Examples in Gözne Plateau of Mersin
}

\author{
Emine Tonus* $\odot$, Hülya Kaynar**
}

Öz

Mersin yöresi yaylalarında dokuma yapan Yörükler tarafından "çul dokuma” adıyla bilinen "ıstar dokumacılığı”nın geçmişi uzun yıllar öncesine dayanmaktadır. Tüm el sanatlarında olduğu gibi, Mersin İli Gözne Yaylası'nda dokunan “ıstar dokumacılı̆ıı”nın devamlılığı sağlanamamış, bu teknik kaybolma tehlikesiyle karşı karşıya kalmıştır. Araştırmada Mersin İli Gözne Yaylası'nda yapılan ıstar dokumacılığı ve günümüze kadar gelen örnekleri incelenerek, yöre dokumacılığının tescillenip, tanıtılması ve Türk kültürüne kazandırılması amaçlanmıştır.

Yörede "ıstar" adı verilen, dikey tezgâh grubundan sarma tip tezgâhlar kullanılmaktadır. Kıl, yün, orlon iplikler kullanılarak "kıllama, tırlık" adı verilen düz dokuma yaygı, namazlık (seccâde), çuval, heybe, yaygı ve köşe çaputu gibi günlük kullanım için üretimler yapılmaktadır.

Yapılan bu araştırmayla zili, cicim ve düz dokuma teknikleri kullanılarak dokunan düz dokuma yaygılardan yirmi farklı ürün incelenmiştir. Araştırmada ürünün dokunma tarihi, dokunma amacı, dokuyan kişi, boyutları, kullanılan iplik türleri, renkleriyle dokumaların teknik, desen, kompozisyon ve motif özelliklerine ait bilgiler yer almaktadır. Veriler yüz yüze görüşme yöntemiyle kaynak kişilerden temin edilmiştir.

Anahtar Kelimeler

Mersin, Gözne, Istar, Dokuma, Desen, Kompozisyon

\begin{abstract}
Istar weaving whose history is based on many years ago, is also known as floor cover weaving by Yürüks weaving in the plateaus of Mersin and have been woven for many years. As in all handcrafts, Istar weaving woven in Gözne plateau located in Mersin cannot be maintained and has been in danger of extinction. The aim of this study is to create a permanent source about local weaving via examining both Istar weaving woven in Gözne plateau located in Mersin and examples survived until today.
\end{abstract}

Winding type looms which are in the group of perpendicular looms are used in the region. Productions such as prayer rug (scatter), sack, saddlebag, ground cloth and corner rug were made by using hair, wool and orlon yarns kıllama, tırlık for daily use.

With this research, twenty different products woven using 'zili', 'cicim' and plain weaving techniques were examined. In the research, the production date of weaving, purpose of weaving, weaver, dimensions, types of yarn used, colors as well as technical, pattern, composition and motif characteristics of weavings are included. The data were obtained from the source persons by face to face interview technique.

\section{Keywords}

Mersin, Gözne, Istar, Weaving, Pattern, composition

* Sorumlu Yazar: Emine Tonus (Öğr. Gör.), Sivas Cumhuriyet Üniversitesi, Sivas Meslek Yüksekokulu, El Sanatları Bölümü, Sivas, Türkiye. E-posta: eminetonus@cumhuriyet.edu.tr ORCID: 0000-0001-5065-1643

** Hülya Kaynar (Doç. Dr.), Sivas Cumhuriyet Üniversitesi, Mimarlık Güzel Sanatlar ve Tasarım Fakültesi, Grafik Bölümü, Sivas, Türkiye. E-posta: hkaynar@cumhuriyet.edu.tr ORCID: 0000-0002-9442-6162

Atıf: Tonus, Emine ve Kaynar, Hulya. “Mersin-Gözne Yaylası'nda Istar Dokumacılığı ve Örnekleri." Art-Sanat, 13 (2020) 387-415. https://doi.org/10.26650/artsanat.2020.13.0016 


\section{Extended Summary}

Istar weaving, which dates back many years, is known as "sackcloths weaving" by Yörüks who weaved in the highlands of Mersin region and has been woven for many years. As in all handicrafts, the continuity of the 1star weaving woven in the Gözne Plateau of Mersin could not be ensured and was in danger of extinction. In this study by examining the weaving made in Gözne Plateau of Mersin and surviving samples it is aimed to register and introduce the regional weaving and to earn it to Turkish culture.

Istar weaving products had great importance in the traditional lives of the region. In the past, they must have been in every dowry because the dowry carried with camels is covered with woven sackcloth. For those who go to see the girls for their son to marry, to look under the rag in the house and get an idea of her cleaning habits and to lay magnificant sackcloths on the belongings during the migration from highlands to the barracks and show them to neighbors were important customs of the region. However, these traditions, such as weaving culture, have been forgotten in recent years.

Wrapping type looms which are from the vertical loom group called "istar" are used in the region. On a loom there are two side trees, two lower and upper "levent" (sündürüm tree), one "gücü" tree, one "varan-gelen (gelen vara)", one "nakış varan-geleni (gelen varas1)", one straight iron, two pieces of iron rod and carpet "cimbar". The side trees located at right angles to the ground and the "sündürüm" trees placed parallel to the ground in the nests on the side trees form the main frame of the loom. Because of wrapping warp rope on the upper "sündürüm" tree and weaved part on the lower "sündürüm" tree, these looms are known as wrapping type looms in Anatolia. While "gücü" is taking the task of seperating the warp wires on the back of the warps on the front and providing crossness, "varan gelen" activates the displacement of warps. The carpet "cimbar" is a piece that is carried up after each span weaving to keep the width constant.

"Kirkit", hand scissors, "cimbars" and various yarns are needed for weaving. These yarns are three types as warp, weft and embroidery. In the region, the yarns known as "çözgü" (warp) and thrown longitudinally are called "çözün", the yarns thrown transversely are called "argaç". Goat hair is generally preferred in weft and warp, and sheep wool is preferred in embroidery. In addition, for benefit from waste yarns, hair and cotton blend yarns called "k1llama" were used in large amounts in weft and warp.

In the region, weaving quality is expressed by "çile". One çile consists of forty single wires and twenty pairs of warp wires. Weavings are woven according to their lengths in two ways as normal and wide, ss the number of warp determines the width of the weaving, ten çile (400 single wire) of normal size and twelve çile (480 single wire) of wide weaving are warped. 
The material of this research is the weaving looms of the 1star weaving in Gözne Plateau of Mersin Province and survived samples of them. Istar weaving samples were examined on site, weavers were interviewed face-to-face and information was obtained and product photographs were taken and documented. In addition, literature review was made and the information obtained was directly or indirectly included in the study.

In this research, twenty different plain woven rug products, woven using 'zili', 'cicim' and plain weaving techniques were examined. In the research, the production date of weaving, purpose of weaving, weaver, dimensions, types of yarn used, colors as well as technical, pattern, composition and motif characteristics of weavings are included. The data were obtained from the source persons by face to face interview technique.

In the region, (prayer rugs), saddlebags, flour sacks, wheat sacks, pillion saddlebags, corner sackcloths and various sizes of floor covering samples woven by using cicim, zili and plain weaving techniques were found. These weavings are very similar in terms of their composition features and the motif characteristics. On the other hand, the motifs are designed in five different ways: simple order, oblique, alternate arrangement of the same motif, rhombus segmentation, horizontal and vertical composition. As a result of research on twenty samples, except regional motifs known as "satranç, köşşek tabanı (regional name of baby camel), tabakalı zili, güllü, dilikli zili and çıngıllı zili”; complementary motifs like "pıtrak, eğri su, küpe, elibelinde, sığır sidiği, yıldız, bereket, ala boncuk, göz, elti eltiye küstü, çengel, gül and lale" were also used.

These weavings, which were dyed naturally in the past, were made with wool, hair, "k1llama", orlons and cotton which were ready dyed in recent years. White, black, gray, blue, red, green, walnut green, "cengari” green, yellow, henna yellow, orange, purple, pink and navy colors were preferred in the Gözne weaves. These weaves These were made for daily use of family members or dowry rather than for commercial purposes.

Gözne presents convenient conditions for weavingin terms of geopolitical location, climate and vegetation suitable for agriculture and animal husbandry and human resources. In addition to considering the charm of modern life to be the main factor in distancing the local people from traditional values; marketing problem, the facts that hand weaving requires intensive labor, time and patience and comes out of the income generating profession has reduced the interest in these and similar arts.

Within the scope of the protection of cultural assets, it is necessary to support the weaving such as istar etc., accepted as ancestor art, by public institutions or private sectors. A market opportunity for woven products and courses or hobby centers to be opened with the awareness of keeping a culture alive will play an important role in the desire of the local people to keep this art alive. 


\section{Giriş}

İnsanlar ihtiyaçlarını karşılamak üzere doğada bulunan hammaddeleri el ile işleyerek çeşitli el sanatı ürünleri ortaya çıkarmışlardır. Bu ürünler, yaşanılan bölgeye, iklim ve bitki örtüsüne, örf ve âdetlerine göre şekillenerek, her yörenin kendi karakteristik özelliklerini meydana gelmiştir. "Türkler, Anadolu' da yerleşik düzene geçtikten sonra, günlük hayatlarının bir parçası hâline getirdikleri el sanatlarıyla yaşadıkları bölgenin özelliklerini harmanlayarak geleneksel, özgün ve tarihi eser niteliğinde ürünler meydana getirmişlerdir." Çeşitli sebeplerden dolayı kaybolmaya yüz tutan bu değerli el sanatlarımızdan biri de Mersin İli Gözne Yaylası'nda yapılan “1star dokumacılığı”dır. Konuyla ilgili daha önce bir akademik çalışma bulunmadığından unutulmaya yüz tutmuş bu dokuma tekniğini bilim dünyasına tanıtma gerekliliği duyulmuştur.

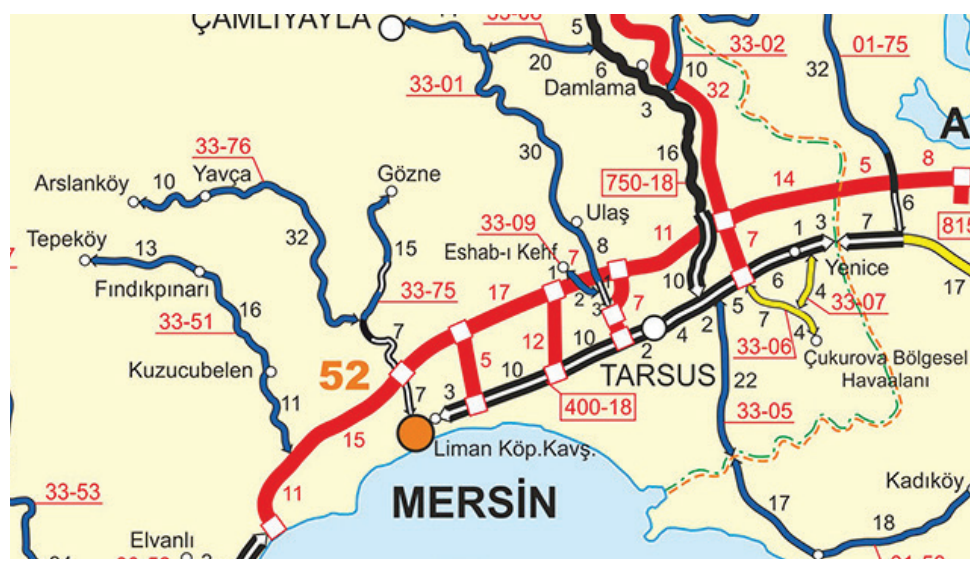

G. 1. Gözne Yaylası Haritası "Gözne harita KGM," erişim 25 Nisan 2019, https:/www.kgm.gov.tr/SiteCollectionImages/KGMimages/Haritalar/b5.jpg

Akdeniz ikliminin hüküm sürdüğü Mersin'de yazların çok sıcak geçmesi, bölgede yayla turizminin gelișmesini sağlamıştır. Gözne, Mersin'in önemli yaylalarından biridir:

Bolkar Dağlarının Akdeniz'e bakan yüzlerinde vadilerle parçalanmış plato düzlükleri üzerinde bulunan Gözne, Mersin il merkezine 26 km mesafededir. En yüksek yeri 1900 m olan Gözne Kalesi'dir. En düşük yeri ise 915 metredir. Çok eski bir tarihe sahip Gözne'de, Greklerin, Aramilerin yaşadığı sanılmaktadır. Mersinlilerin Gözne'yi yayla edinmeleri çok yeni sayılmaz. Tarsus'ta ikamet eden Debbas ismindeki bir Rum vatandaşının, av nedeni ile ormanların içerisinde gördüğü Gözne’yi, yaz sıcaklarında yayla şeklinde kullanması ile başlamıştır. Debbasla birlikte diğer gayrimüslimler de Gözne 'ye gelmişler ve zamanla bu yerleşim genişlemiştir. Çukurova Fransızlar tarafindan işgal edilince, bilhassa Mersinli halk Gözne'ye kaçmıştır. Halk dilinde buna kaç-kaç denilmekte ve tarihi bir dönem gibi anılmaktadir ${ }^{2}$.

1 Hülya Kaynar ve Emine Tonus, "Kangal Yöresine Ait Bir Grup Anadolu Halısının Teknik ve Desen Analizi," Art-Sanat 10 (Ocak 2018): 233, erişim 29.12.2019, http://doi.org/10.26650/artsanat.2018.10.0009.

2 H. Şinasi Develi, Dünden Bugüne Mersin (Mersin: Mersin Büyükșehir Belediye Yayınları, 2008), 18-20. 
Gözne, Mersin'in aksine, Akdeniz ikliminden kopuk, tipik karasal iklimin hüküm sürdüğü bir yerleşim birimidir. Tarım ve hayvancılığa elverişli bu topraklar, halkın geçimini idame ettirmesinde önemli rol oynamaktadır. Ancak, Anadolu’nun pek çok yerleşim merkezinde olduğu gibi, Gözne' de de insanlar tarım ve hayvancılıktan uzaklaşmış, modern yaşam koşullarında kendilerine yer bulma çabasına girmişlerdir. Kışın kar, yazın ise yayla turizmine elverişli bu yörede, yaz-kış nüfusu arasındaki fark epeyce fazladır. Özellikle kamu ya da özel sektörlerce desteklenen iş imkânlarının bulunmamasından dolayı, yıllar içerisinde özellikle kış nüfusu azalmıştır. Geçmişte koyun, keçi gibi küçükbaş hayvan yetiştiriciliğinin yapılması yöre insanını çeşitli el sanatlarına yönlendirmiştir. Özellikle artık iplik, penye ve çeşitli kumaşların değerlendirildiği yatay tezgâhlar kullanılarak yapılan çulfalık dokumacılığı (pedallı tezgâh) ile keçi kılı, koyun yünü ve pamuğun kullanıldığı dikey tezgâhlarda yapılan 1star dokumacılığg, bu sanatların başında gelmektedir. Kilim, cicim ve zili tekniklerinin uygulandığı ıstar tezgâhlarda, yöre halkı tarafından hazırlanan hammadde kullanılarak, ananevi motiflerle bezeli dokumalar yapılmıştır.

İki veya daha çok iplik grubunun, çeşitli şekillerde, birbiri arasından, altından, üstünden geçirilerek meydana getirilen ürüne dokuma denir. Dokumalar, yatay ipler (atkl), dikey iplerin (çözgü) arasından, altından, üstünden geçirilerek meydana getirilir. Anadolu'da, iki veya daha çok iplikle yapılan, yer sergisi, örtü, perde vb. amaçlarla kullanılan dokumalara düz dokuma yaygı denir. Bunlar da kendi arasında, kilim, cicim, zili (sili), sumak (verneh) gibi çeşitlilik gösterir. ${ }^{3}$

Geçmişi uzun yıllar öncesine dayanan 1star dokumaları, yörenin geleneksel yaşantıları içerisinde büyük öneme sahipti. Develerle taşınan çeyizin üzeri dokuma çullarla örtüldüğü için mutlaka her çeyizde bulunması gerekirdi. Bunun dişında oğullarına kız görmeye gidenler, evdeki serili çulun altına bakarak kızın temizlik alışkanlığ hakkında fikir edinirlerdi. Ayrıca yayladan kışlağa göç sırasında, eşyaların üzerine görkemli çullar serilerek komşulara gösterilmesi de yörenin önemli âdetlerindendi. Dokumacılık kültürü gibi bu gelenekler de günümüzde unutulmuştur.

Çalışmamızda kullandığımız Istar dokuma örnekleri yerinde incelenmiş, dokuyucularla yüz yüze görüşülerek bilgiler alınmış ve ürün fotoğrafları çekilerek belgelenmiştir. Ayrıca konuyla ilgili kaynak taraması yapılmış, elde edilen bilgiler ise doğrudan veya dolaylı bir şekilde çalışmaya dâhil edilmiştir.

\section{Gözne Istar Dokumacılığg}

Gözne Yaylası 1star dokumacılığında kullanılan araç gereçler, tezgâh, kirkit, el makası ve renkli ipliklerdir.

3 Bekir Deniz, Türk Dünyasında Hall ve Düz Dokuma Yaygıları (Ankara: Atatürk Kültür Merkezi Yayını, 2000), 57. 


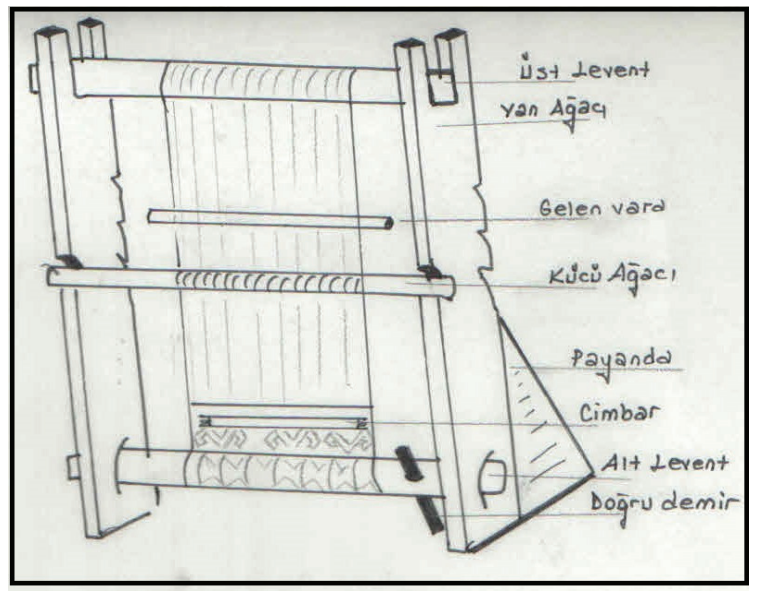

G. 2. Istar dokuma tezgâhı (Emine Tonus, 2019)

Konar-göçer yaşam kültürüne uygun biçimde temin edilmesi, kurulması ve sökülmesi kolay, Isparta veya çözgü sarmalı dikey tezgâhlar yörede "Istar" diye isimlendirilmektedir. Bir tezgâhta, iki adet yan ağac1, iki adet alt levent-üst levent (sündürüm ağac1), bir adet gücü (kücü) ağacı, bir adet varan-gelen (gelen vara), bir adet nakış varan-geleni (gelen varası), bir adet doğru demir, iki adet demir çubuk ve halı cimbarı bulunur. Zemine dik açıyla konum alan yan ağaçlarla yan ağaçlar üzerindeki yuvalara zemine paralel şekilde yerleştirilen sündürüm ağaçları tezgâhın ana iskeletini meydana getirir. Üst sündürüm ağacına çözgü ipi, alt sündürüm ağacınaysa dokunan kısım sarılması nedeniyle bu tezgâhlar Anadolu'da "sarma tip" ismiyle de bilinmektedir. Gücü (kücü), arkadaki çözgü telleriyle öndeki çözgüleri birbirinden ayırması ve çaprazlık sağlaması görevini üstlenirken varan gelen çözgülerin yer değiştirme işlemini harekete geçirmektedir. Halı cimbarı ise eni sabit tutmak için her bir karış dokuma yapıldıktan sonra yukarıya taşınan bir parçadır.

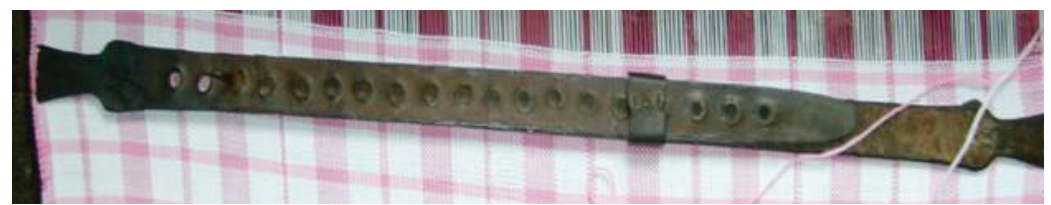

G. 3. Cimbar (Emine Tonus, 2018)

Gözne Yaylası 1star dokumalarında çözgü, atkı ve nakış iplikleri kullanılır. Yörede, çözgü ipine "çözün", enine atılan atkı ipliklerine de "argaç" denilmektedir. Atkı ve çözgüde genellikle keçi kılı tercih edilirken, nakışta koyun yünü kullanılmıştır. Ayrıca atık ipliklerin değerlendirilmesi için "kıllama" adı verilen kıl ve pamuk karışımı iplikler de atkı ve çözgüde fazla miktarda kullanılır. Keçi kıllarının taranması esnasında uzun lifler ip yapımı için ayırılırken, tarak altına düşen kısa lifler atılmayıp yörede "tırlık" adı verilen pamuk harmanına karıştırılır ve yay ile kıllama yapımında değerlendirilir. 
Dokumalarda kullanılan keçi kılı ya da koyun yünleri Ağustos ayında kırkılmaktadır. Kırkılan lifler iyice yıkanır, kurutulur, didilerek içindeki her türlü pıtrak, gübre artıkları, sap ve çöplerden arındırılır. Daha sonra şerit hâline getirilen bu lifler, oklavayla kıvırılarak kol içinden geçecek şekilde eğirilmek için hazırlanır. Kirmenle eğirilen ipler, "1lgıdır, kecefe" veya iki diz arasında çile hâline getirilir. Her iki tarafından iplerle bağlanıp boyamaya hazır duruma gelen çileler, kimyasal boyayla boyanır ve sonra yumak yapilır.

Istar tezgâhlar, çözgüler ayrı bir yerde çözüldükten sonra, tezgâh üzerine aktar1mın yapılmasını gerekli kılmaktadır. Dokuma uzunluğu belirlendikten sonra karşılıklı iki kazık çakılır. Çözgü hazırlama işıemi üç kişi tarafından yapılır. Bir kişi kazıklar arasında çözgüyü dolarken, diğer iki kişi kazıkların başına oturarak zincir örgü (zincirleme) işlemini yapar. Her dört adet çözgü bir grup kabul edilir ve ortada bulunan kişi, on grup (kırk adet) çözgü çözer. Yörede dokuma kalitesi çileyle ifade edilir. Bir çile kırk tek tel (yirmi çift) çözgü telinden meydana gelir. Dokumalar enlerine göre, iki şekilde (normal ve enli) dokunur. Çözgü sayısı dokumanın enini belirlediği için, normal ebatlarda on çile (dört yüz tek tel), enli dokumalarda ise on iki çile (dört yüz seksek tek tel) çözgü çözülür.

Çözgü çözme işlemi tamamlandıktan sonra çözgüler demir çubuklara aktarılarak, sadece kenar kısımlarından sabitlenir. Düzgün bir şekilde tezgâh önüne taşınan çözgü demiri, önce üst sündürüm ağacındaki demir çubuk yuvasına oturtularak sıkıca bağlanır. Kendi etrafında döndürerek çözgülerin üst sündürüm ağacına sarımı yapılır. Daha sonra alt tarafta kalan demir çubuk da alt sündürüm ağacındaki yuvaya yerleştirilerek sıkıca bağlanır. Alttaki sündürüm ağacına ikişerli üçerli gruplar hâlinde çözgüler, sicim ipiyle sarılır ve aralıkları eşitlenerek sağlamlaştırılır. Bu aşamadan sonra çözgü tarama işlemine geçilir.

Kücü (gücü) ağacı yan ağaçlar üzerindeki yuvalara yerleştirilerek küçüleme işlemi yapılır. Kücü çubuğuna bağlanan küçük bir yumak, varan-gelen ağacının altında kalan çözgünün arkasından geçirilip gücü ipine bağlanır. Öndeki tel bırakılır tekrar arkadaki tel örülür, bu işlem tüm çözgülere uygulanır. Ön ve arka çözgülerin arasına gelen-vara (varan-gelen ağacı), gelen-vara ile kücü (gücü) ağacı arasındaki çaprazaysa daha ince olan nakış gelen-varası (nakış varan-geleni) yerleştirilir.

Dokumaya başlamadan önce, hiç saçak payı bırakılmaz. Birer çift çözgü teli al1narak argaç (atkı) ipiyle kendi etrafında dolanarak dokuma enince zincir örgü yapılır. Arkasından yine argaç ipiyle dört parmak genişliğinde düz dokuma yapılır ve bu kısım dokuma bittikten sonra geriye kıvırılarak dikilir. Dokumanın bitirilme aşamasında da aynı işlemler simetrik şekilde tekrarlanır. Daha sonra dokumanın nakışlı kısmına geçilir. 


\section{Gözne Yaylası'nda Bazı Dokuma Örnekleri}

Yapılan araştırma sonucunda yörede, cicim, zili ve düz dokuma teknikleri kullanılarak, namazla (seccâde), heybe, un çuvalı, buğday çuvalı, terki heybesi, köşe çaputu ve çeşitli büyüklüklerde yer yaygısı örneklerine rastlanmıştır. Terki heybesi, beyaz pamuk iple yapılan zemin üzerine, boyalı yünlerle model konularak süslenen ve ata binen gelinlerin altına serilen özel bir dokumadır. Terki heybesinde genellikle elibelinde ve eğer kaşı gibi modeller dokunur. Köşe çaputu ise, konumları gereği biraz ön tarafta duran ocakların, yan tarafında yer yaygılarıyla kapatılamayan boşluklara küçük parçalar hâlinde serilen dokumalardır.

Yöre dokumaları, gerek kompozisyon özelliği ve gerekse kullanılan motif karakterleri açısından birbirlerine çok benzemektedir. Motifler, eşkenar dörtgenlerin içine planlanabildiği gibi, yatay ve dikey kompozisyonla basit sıralı, almaşık veya verev kullanılabilir. Yirmi örnek üzerinde yapılan araştırmada, "satranç, köşşek tabanı, tabakalı zili, güllü, dilikli zili ve çıngıllı zili” isimleriyle bilinen dokumalar incelenmiştir.

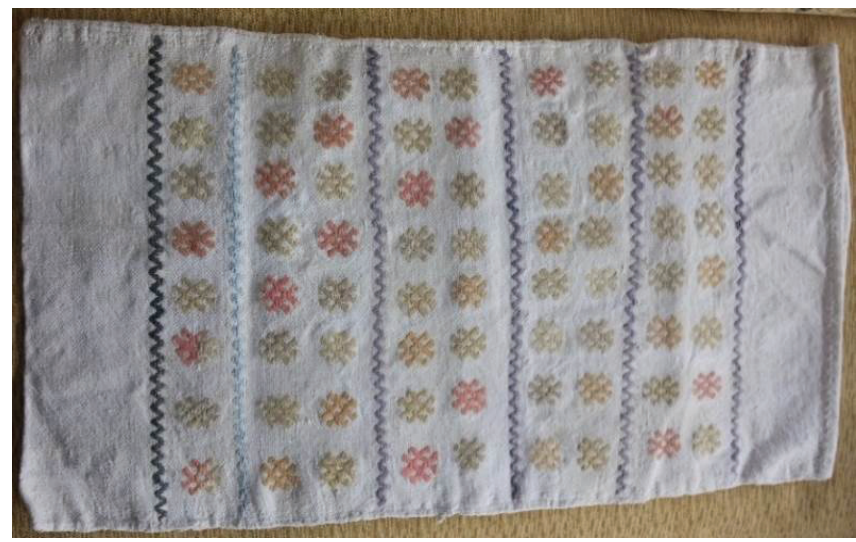

G. 4. Bulgur çuvalı ön yüzü (Emine Tonus, 2018)

Gözlemin yapıldığı yer: Gözne / Mersin

Ürünün sahibi: Ayşe Hanım (1946)

Ürünü dokuyan kişi: Ayşe Hanım (1946)

Gözlemin yapıldığı tarih: 16.08.2018

Ürünün dokunduğu tarih: 1962

Oluşturulan ürün-eşya: Bulgur çuvalı

Ürünün boyutları: 49 x $92 \mathrm{~cm}$

Kullanılan iplik türleri: Çözün-Argaç: Tırlık, Nakış: Orlon

Kullanılan renkler: Beyaz, siyah, mavi, kırmızı, cevizi yeşil, kınalı sarı, gri

Ürüne verilen genel ad: Çuval

Dokumada kullanılan desenleme tekniği: Cicim teknikli

Kullanılan motif isimleri: Tek gözlü pıtrak, eğri su 
Kompozisyon özellikleri : Yatay kompozisyonlu tasarlanan çuval, bolluk, bereket ve aynı zamanda nazarlardan korunma anlamındaki pıtrak motifiyle bezenmiştir. "Pıtrak, adını aldığı bitkinin temsiliyetinden başka bir şey değildir ve bol meyve veren başak ya da nar gibi bitkisel özelliğinden dolayı bereketi simgeler." ${ }^{* 4}$ Çözgü (çözün) ve atkıda (argaç) yörede "tırlık" diye adlandırılan pamuk ip, nakışlardaysa orlon iplikler kullanılmıştır. Basit sıralı yerleştirilen tek gözlü pıtrak motifleri her iki sırada bir "eğri su" motifiyle yatay yönde gruplandırılmıştır. Motifler, bir sıranın üç kez tekrarlanması suretiyle meydana gelir. Ön yüzü pıtrak ve eğri suyla bezeli bulgur çuvalının arka yüzüyse tek renklidir. Dokuma ön ve arka yüzün beraberce dokunduktan sonra ikiye katlanıp, yanlardan dikilmesi suretiyle çuval hâline getirilmiştir.

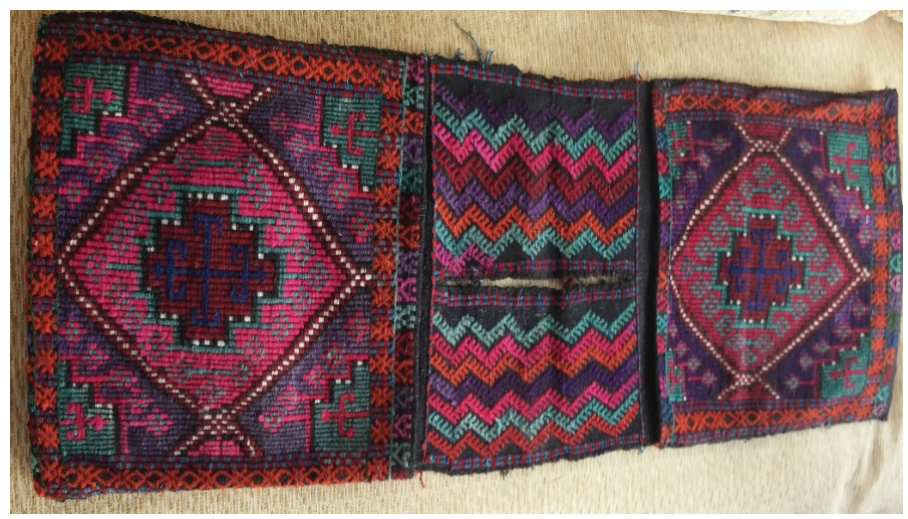

G. 5. Terki Heybesi ön yüzü (Emine Tonus, 2018)

Gözlemin yapıldığı yer: Gözne / Mersin

Ürünün sahibi: Ayşe Hanım (1946)

Ürünü dokuyan kişi: Ayşe Hanım (1946)

Gözlemin yapıldığı tarih: 16.08.2018

Ürünün dokunduğu tarih: 1963

Oluşturulan ürün-eşya: Heybe

Ürünün boyutları: $43 \times 125 \mathrm{~cm}$

Kullanılan iplik türleri: Çözün- Argaç: Tırlık, Nakış: Orlon

Kullanılan renkler: Mor, turuncu, kırmızı, yeşil, pembe, lacivert, beyaz, siyah, cengari yeşil

Ürüne verilen genel ad: Terki heybesi

Dokumada kullanılan desenleme tekniği: Zili teknikli

Kullanılan motif isimleri: Çıngıllı zili, tek gözlü pıtrak, küpe, sığır sidiği

Kompozisyon özellikleri: Heybe ceplerinden biri 43 x $46 \mathrm{~cm}$ iken diğeri 42 x 47 cm'dir. 21 x $32 \mathrm{~cm}$. ebatlarındaki iki adet şak ile birbirine bağlanmıştır. Heybenin ön yüzü geometrik merkezine göre tam simetrik bezenmiş ve köşe-göbekli bir tasarımdır.

4 Ahmet Diler ve Marc-Antoine Gallice, Kilimin Sembolleri (İstanbul: Alfa Basım Yayım Dağıtım Ltd. Şti., 2018), 100. 
Dokuma merkezine yörede "çıngıllı zili" diye adlandırılan motif yerleştirilmiştir. Bu motif, salkım şeklinde göz motiflerinin bağl1, basamaklı sekizgen ile onun içindeki karşıllklı elibelinde ve koçboynuzu motiflerinden meydana gelmiştir. Köşelerde ise çıngıllı zili motifinin $1 / 4$ oranındaki çeyrek tasarımları kullanılmıştır. Heybe deseni dört taraftan tek gözlü pitrak motifiyle çerçeve içine alınırken, dokumanın ayak kısmında başlangıç ve bitişlerde ise küpe motifleri dokunmuştur. 21 x $32 \mathrm{~cm}$ ebatlarındaki iki adet şak, dikey kompozisyonlu, çeşitli renklerdeki sığır sidiği motifinin sonsuza uzanması şeklinde tasarlanarak heybe ceplerine aplike edilmiştir. "Siğır sidiği ismiyle adlandırılan akarsu teması, bereketi simgelemek üzere kullanılmıştır." Ön yüzü desenli heybenin arka yüzü, çözünde ve argaçta siyah tırlık kullanılması nedeniyle desensiz bırakılmıştır.

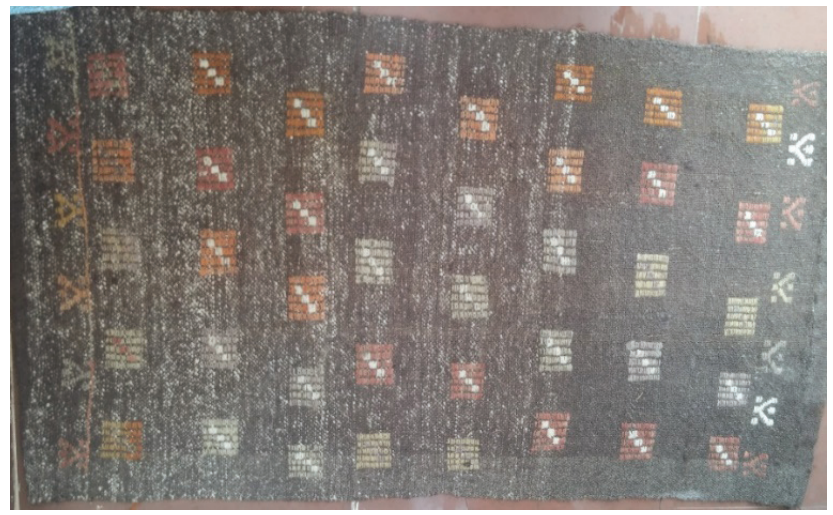

G. 6. Köşe çaputu ön yüzü (Emine Tonus, 2018)

Gözlemin yapıldığı yer: Gözne / Mersin

Ürünün sahibi: Meryem Tömen (1965)

Ürünü dokuyan kişi: Teslime Şahin (Merhume)

Gözlemin yapıldığı tarih: 17.08.2018

Ürünün dokunduğu tarih: 1978

Oluşturulan ürün-eşya: Köşe örtüsü

Ürünün boyutları: 76 x $152 \mathrm{~cm}$

Kullanılan iplik türleri: Çözün - Argaç: Kı1, pamuk karışımı, Nakış: Yün

Kullanılan renkler: Siyah, kırmızı, kınalı sarı, gri, beyaz, sarı, yeşil

Ürüne verilen genel ad:Köşe çaputu

Dokumada kullanılan desenleme tekniği: Zili teknikli

Kullanılan motif isimleri:Tek kanatlı satranç (kare şeklinde dizilmiş motifler) küpe

Kompozisyon özellikleri: Dokuma, tek kanatlı ve yörede "satranç" ismiyle bilinen motifin yer yer basit sıralı, yer yer de almaşık sıralanmasıyla tamamen serbest

5 Türk El Dokuması Halılar (Ankara: T.C. Kültür ve Turizm Bakanlığı, Döner Sermaye İşletmesi Merkez Müdürlüğ̈̈ Yayını, [t.y] ), Katalog:1, TEH Model Kodu: 0083. 
düzende planlanmıştır. Ayrıca zeminde kullanılan düz dokumanın büyük bir bölümü kıllama denilen pamuk ve k1l karışımı iplikle dokunurken küçük bir bölümünde de sadece kıl tercih edilmiştir. Tek kanatlı satranç olarak tanımlanan motif, kare şeklindeki geometrik düzenin içine farklı renkteki başka bir iple verev noktalar konulmasından meydana gelmiştir. Yörede "dokumanın ayak motifi" ismiyle ifade edilen, yatay eksendeki başlangıç ve bitiş noktalarındaki dar kenar sularında ise küpe motifleri kullanılmıştır.

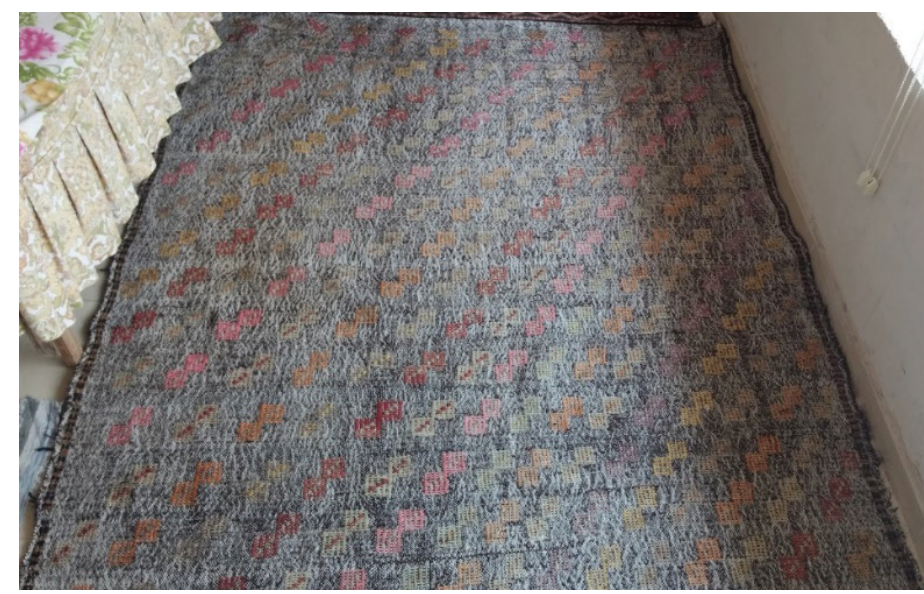

G. 7. Çul yaygı örneği (Emine Tonus, 2018)

Gözlemin yapıldığı yer: Gözne / Mersin

Ürünün sahibi: Meryem Tömen (1965)

Ürünü dokuyan kişi: Teslime Şahin (Merhume)

Gözlemin yapıldığı tarih: 17.08.2018

Ürünün dokunduğu tarih: 1977

Oluşturulan ürün-eşya: Çul yaygı

Ürünün boyutları: 170 x $270 \mathrm{~cm}$

Kullanılan iplik türleri: Çözün ve argaç: Kı1, pamuk karışımı, Nakış: Yün

Kullanılan renkler: Siyah, beyaz, kınalı sarı, kırmızı, pembe, sarı, cevizi yeşil, gri, mor

Ürüne verilen genel ad: Çul yaygı

Dokumada kullanılan desenleme tekniği: Zili teknikli

Kullanılan motif isimleri: Yarım Satranç

Kompozisyon özellikleri: Dokuma, k1llama zemin üzerine farklı renklerdeki "yarım satranç" motiflerinin verev yerleşiminden meydana gelmiştir. İki adet tek kanatlı satranç motifinin verev bileşiminden yarım satranç motifi meydana gelir. ${ }^{6}$

6 Satranç ve yarım satranç ifadeleri kaynak kişilere aittir. 


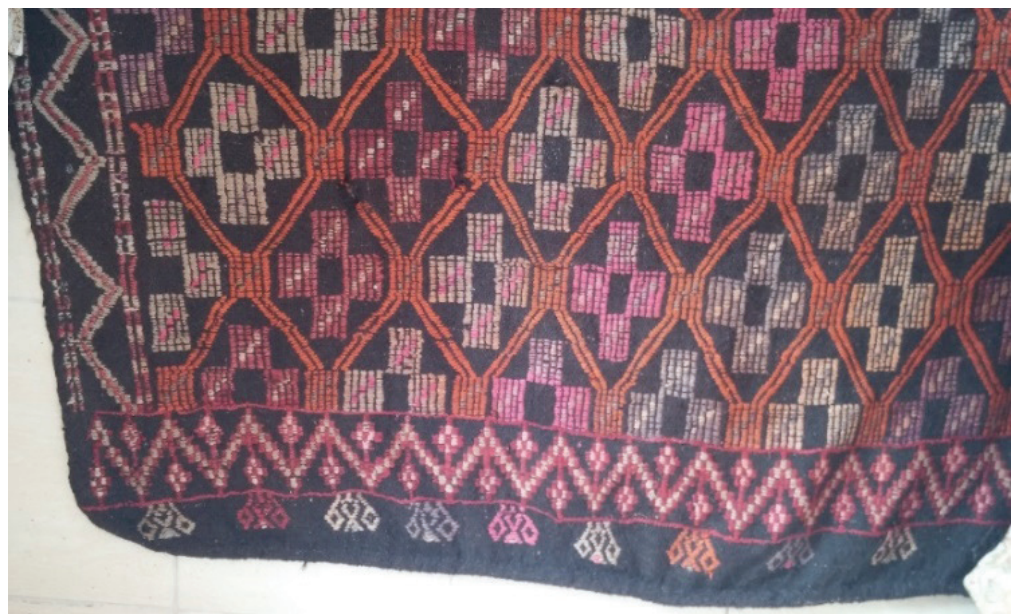

G. 8. Çul yaygı örneği (Emine Tonus, 2018)

Gözlemin yapıldığı yer: Gözne / Mersin

Ürünün sahibi: Meryem Tömen (1965)

Ürünü dokuyan kişi: Bilinmiyor

Gözlemin yapıldığı tarih: 17.08.2018

Ürünün dokunduğu tarih : 1960

Oluşturulan ürün-eşya: Çul yayg1

Ürünün boyutları: 180 x $280 \mathrm{~cm}$

Kullanılan iplik türleri: Çözün - Argaç: Kı1, Nakış: Yün

Kullanılan renkler: Siyah, kırmızı, pembe, kınalı sarı, beyaz, mor, açık mavi

Ürüne verilen genel ad: Çul yayg1

Dokumada kullanılan desenleme tekniği: Zili teknikli

Kullanılan motif isimleri: Satranç eğri su, çiçekli eğri su, küpe

Kompozisyon özellikleri: Dokuma, uzun kenarda bir adet geniş ayak, kısa kenardaysa bir adet dar ve bir adet de geniş ayakla çerçeve içine alınmıştır. Uzun kenar geniş ayağında yalın kullanılan eğri su, kısa kenarda çiçekli eğri su şeklinde detaylandırılmıştır. Ayrıca dokumanın başlangıç ve bitişindeki kısa kenar dar ayağındaysa küpe motifinin kullanıldığı görülmüştür. Dokumanın zemini eşkenar dörtgenler hâlinde bölümlere ayrılmış ve her birinin içi artı "+” şeklindeki "satranç" motifiyle doldurulmuştur. Yörede dokumalar yarım motif ile başlayıp yine yarım motif ile bitirilirken, her bir satranç motifinin arası yörede "sarı çatkı" denilen suyoluyla ayrilmıştır. 


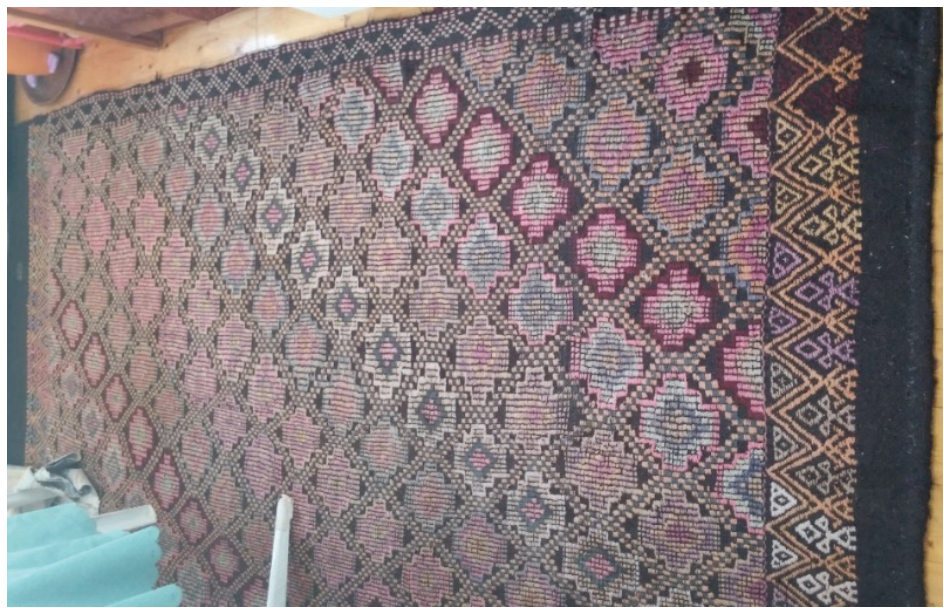

G. 9. Çul yaygı örneği (Emine Tonus, 2018)

Gözlemin yapıldığı yer: Gözne / Mersin

Ürünün sahibi: Meryem Tömen (1965)

Ürünü dokuyan kişi: Bilinmiyor

Gözlemin yapıldığı tarih: 17.08.2018

Ürünün dokunduğu tarih: 1960

Oluşturulan ürün-eşya: Mutfak çulu

Ürünün boyutları: 167 x $280 \mathrm{~cm}$

Kullanılan iplik türleri: Çözün - Argaç: Kı1, Nakış: Yün

Kullanılan renkler: Pembe, bordo, mavi, sarı, yeşil, siyah, mor, gri

Ürüne verilen genel ad: Çul yaygı

Dokumada kullanılan desenleme tekniği: Zili teknikli

Kullanılan motif isimleri: Köşşek tabanı, eğri su, elibelinde, küpe

Kompozisyon özellikleri: Çözgü ve atkısı kıl, çul yaygının başlangıç ve bitişinde on beşer cm'lik düz dokuma yapılmış ve ikişer $\mathrm{cm}$ geriye kıvrılarak dikilmiştir. Dokumada kısa ve uzun kenarlarda birer adet geniş ayak ve zemin kompozisyonu vardır. Uzun kenar geniş ayağında yalın biçimde kullanılan eğri su, kısa kenar ayaklarında elibelinde ve küpe motifleriyle zenginleştirilmiştir. Zemin, almaşık düzende sonsuza doğru uzanan eşkenar dörtgen ile her bir eşkenar dörtgenin içine yerleştirilmiş "köşşek tabanı” motifinden meydana gelmiştir. Köşşek, yörede deve yavrusuna verilen isimdir. Yavru devenin ayak izine benzetilmesi nedeniyle de motife "köşşek tabanı” denildiği düşünülmektedir. Basamaklı sekizgen içine farklı renklerde iç içe tasarlanmış eşkenar dörtgen görünümlü motifler ara suyu kullanılarak birbirlerinden ayrılmıştır. Yöre kültürüne uygun yarım motifle başlanan dokuma, yine yarım motifle bitirilmiştir. 


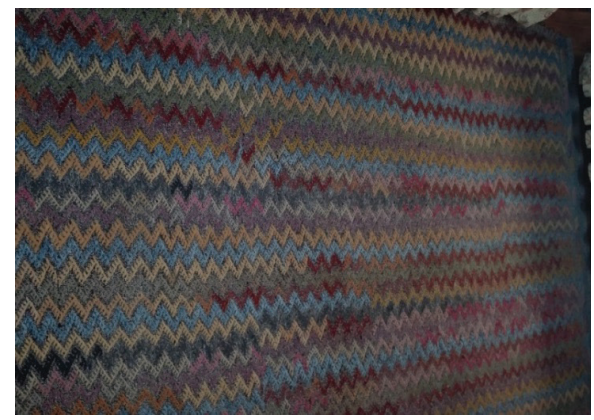

G. 10. Çul yaygı örneği (Emine Tonus, 2018)

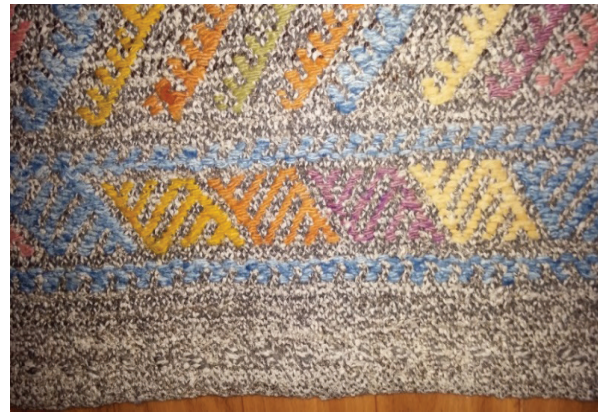

G. 11. Çul yaygı kenar suyu detayı (Emine Tonus, 2018)

Gözlemin yapıldığı yer: Gözne / Mersin

Ürünün sahibi :Meryem Tömen (1965)

Ürünü dokuyan kişi: Bilinmiyor

Gözlemin yapıldığı tarih: 17.08.2018

Ürünün dokunduğu tarih: 1960

Oluşturulan ürün-eşya: Çul yayg1

Ürünün boyutları: 205 x $281 \mathrm{~cm}$

Kullanılan iplik türleri: Çözün - Argaç: Kı1, pamuk karışımı, Nakış: Orlon

Kullanılan renkler: Siyah, beyaz, mavi, sarı, kırmızı, yeşil, kınalı sarı, pembe, mor, gri,

Ürüne verilen genel ad: Çul yayg1

Dokumada kullanılan desenleme tekniği: Zili teknikli

Kullanılan motif isimleri: Sığır sidiği, elti eltiye küstü, eğri su

Kompozisyon özellikleri: Kisa kenarlarda birer adet geniş ayak bulunan dokuma, dikey kompozisyonla tasarlanmıştır. Yörede kıllama adı verilen pamuk, kıl karışımı atkı ve çözgü üzerine renkli orlonlarla karışık biçimde sığır sidiği motifi dokunmuştur. Çul üzerindeki renkler düzensiz bir dizilim sergilemektedir. Sınırları eğri suyla belirlenmiş olan geniş ayaklardaysa "elti eltiye küstü” motifi uygulanmıştır. Tarak motiflerinin sırt sırta durması nedeniyle yörede bu ismi aldığg düşünülmektedir. 


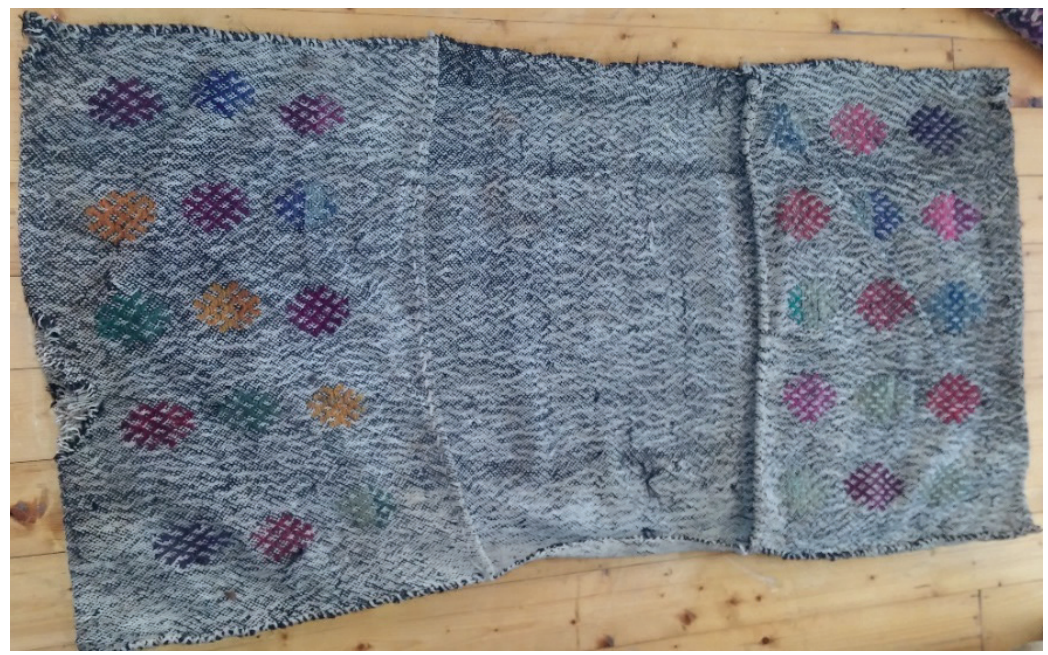

G. 12. Çul heybe ön yüzü (Emine Tonus, 2018)

Gözlemin yapıldığı yer: Gözne / Mersin

Ürünün sahibi: Meryem Tömen (1965)

Ürünü dokuyan kişi: Teslime Şahin (Merhume)

Gözlemin yapıldığı tarih: 17.08.2018

Ürünün dokunduğu tarih: 1980

Oluşturulan ürün-eşya: Çul heybe

Ürünün boyutları: 69 x $130 \mathrm{~cm}$

Kullanılan iplik türleri: Çözün - Argaç: Kı1, pamuk karışımı, Nakış: Yün

Kullanılan renkler: Siyah, beyaz, kırmızı, pembe, mavi, yeşil, mor, kınalı sarı, lacivert

Ürüne verilen genel ad: Heybe

Dokumada kullanılan desenleme tekniği: Cicim teknikli

Kullanılan motif isimleri: Pitrak

Kompozisyon özellikleri: Yekpare biçimde dokunan heybe, nakışlı kısımlarından geriye katlanarak yanlardan dikilmek suretiyle cepler meydana gelmiştir. Çözün ve argacında kıllama kullanılan heybenin her iki cebinde yan yana beşer, üst üste üçer adet pitrak motifinin basit sıralı yerleşimi görülmektedir. Ancak, bir cepte dört, diğer cepte ise dokuz gözlü pıtrak kullanıldığı dikkat çekmiştir. 


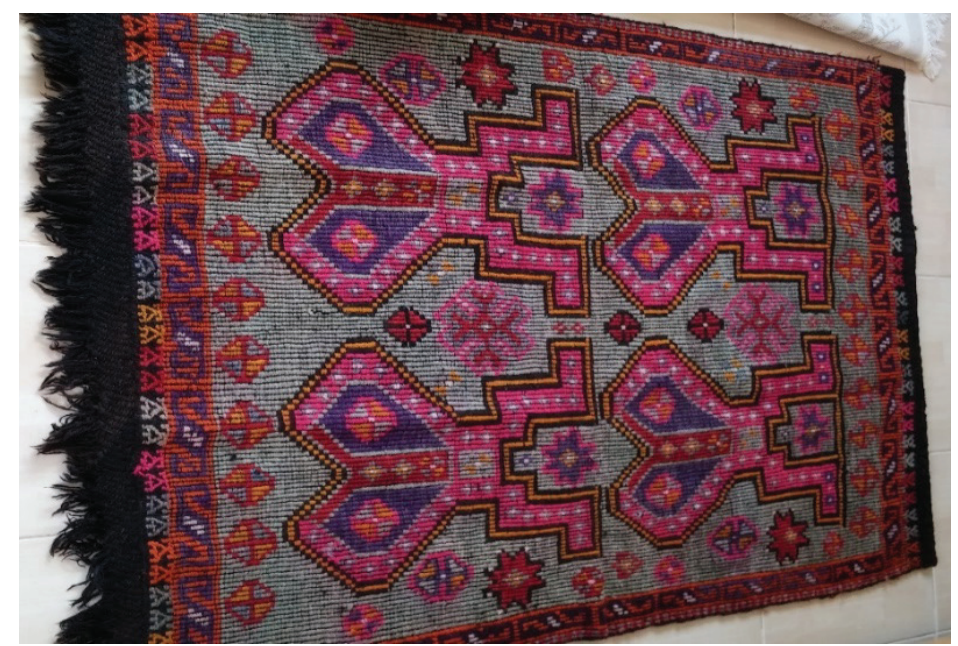

G. 13. Çul seccade ön yüzü (Emine Tonus, 2018)

Gözlemin yapıldığı yer: Gözne / Mersin

Ürünün sahibi: Nevin Şahin (1966)

Ürünü dokuyan kişi: Nevin Şahin, Vehibe Şahin

Gözlemin yapıldığı tarih: 23.08.2018

Ürünün dokunduğu tarih: 1983

Oluşturulan ürün-eşya: $\operatorname{Namazla}^{7}$ (Seccâde - Çift kişilik)

Ürünün boyutları: 112 x $136 \mathrm{~cm}$

Kullanılan iplik türleri: Çözün, argaç, nakış: Yün

Kullanılan renkler: Siyah, kınalı sarı, cengari yeşil, sarı, mor, pembe, mavi, kırmizi.

\section{Ürüne verilen genel ad: Namazla}

Dokumada kullanılan desenleme tekniği: Zili teknikli

Kullanılan motif isimleri: Küpe, çengel, göz, yıldız, fiyonk şeklinde düzenlenmiş çiçek

Kompozisyon özellikleri: Örnekte çift kişilik seccâde görülmektedir. Bu zeseccâde geometrik merkezinden düşey konumda iki eşit parçaya ayırıldığında tek kişilik seccâde biçimine gelmektedir. Kısa kenarlarda iki, uzun kenarlarda bir adet ayakla çerçeve içine alınan seccâde dikey kompozisyonla tasarlanmıştır. Çengelli su, dört bir taraftan dokumayı çevrelerken küpe motifleri sadece kısa kenarlarda kullanılmıştır. Yan yana ve üst üste ikişer adet mihrap motifi seccâdenin ana karakteri olarak ortaya çıkmaktadır. Zemin boşluklarıysa göz, yıldız ve fiyonk şeklinde düzenlenmiş çiçeklerle doldurulmuştur.

7 Namazlağı üstünde namaz kılınan seccâde olarak bilinmektedir. "Namazlağı”, Güncel Türkçe Sözlük, erişim 25.01.2020. https://sozluk.gov.tr ; Yörede namaz k1lmak için seccâde ya da namazlağ/namazla yere serilir. Çalışmada yörede kullanılan şekliyle yazılması uygun görülmüştür. 


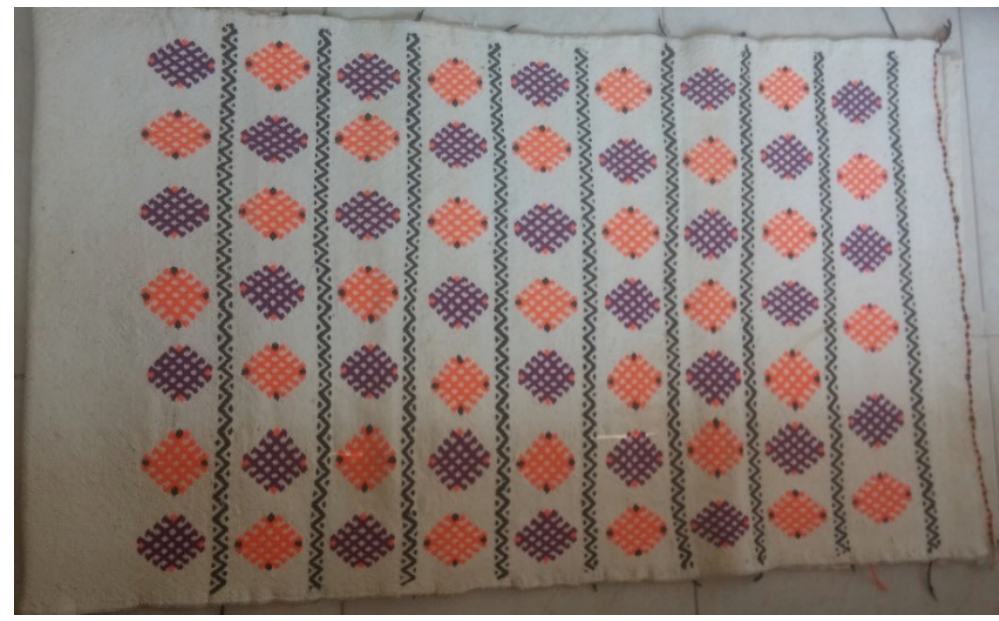

G. 14. Un çuvalı (Emine Tonus, 2018)

Gözlemin yapıldığı yer: Gözne / Mersin

Ürünün sahibi: Vehibe Şahin (1945)

Ürünü dokuyan kişi: Nimet Sarı (Merhume)

Gözlemin yapıldığı tarih: 23.08.2018

Ürünün dokunduğu tarih: 1977

Oluşturulan ürün-eşya: Un çuvalı

Ürünün boyutları: $66 \times 121 \mathrm{~cm}$

Kullanılan iplik türleri: Çözün - Argaç: Kıl, pamuk karışımı, Nakış: Orlon

Kullanılan renkler: Siyah, beyaz, turuncu, mor

Ürüne verilen genel ad: Çuval

Dokumada kullanılan desenleme tekniği: Cicim teknikli

Kullanılan motif isimleri: Pıtrak, eğri su

Kompozisyon özellikleri: Ön ve arka yüzün yekpare dokunduğu un çuvalı ortadan ikiye katlanıp, yanlardan dikilmek suretiyle oluşmuştur. Yan yana yedi, üst üste dokuz sıra şeklinde tasarlanan ön yüzde toplam altmış üç pıtrak motifi kullanılmıştır. Mor ve turuncu renklerin almaşık biçimde basit sıralı düzendeki yerleşiminden oluşan dokuz gözlü pıtraklar, her sırada eğri sularla gruplandırılarak yatay kompozisyonlu görünüm kazanmışlardır. Un çuvalının arka yüzüyse, tırlık adı verilen kıl ve pamuk karışımlı el eğirmesi iplerden meydana gelen bezayağ dokumadan yapılmıştır. 


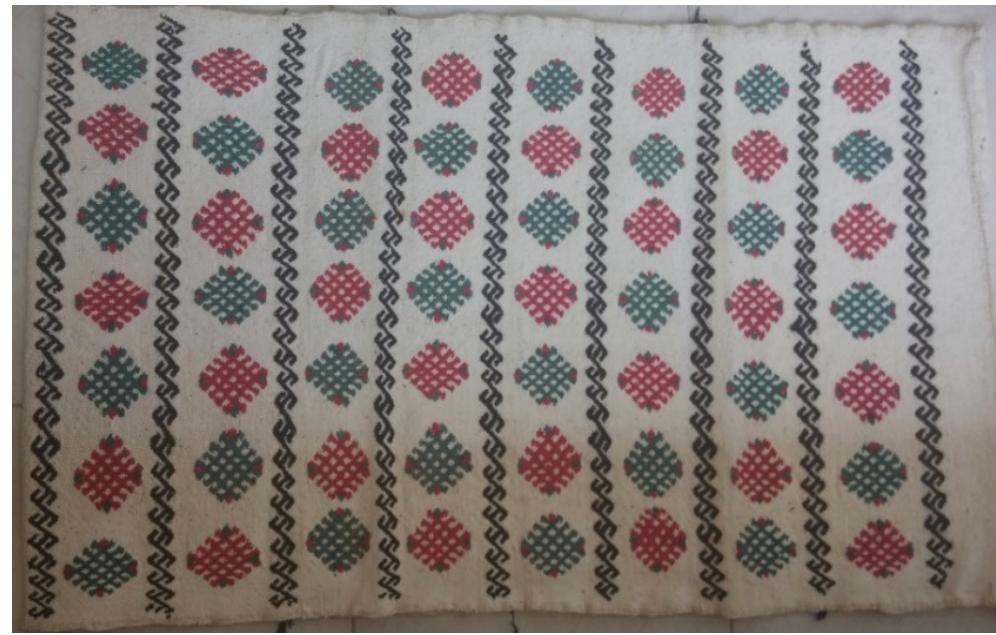

G. 15. Çuval ön yüzü (Emine Tonus, 2018)

Gözlemin yapıldığı yer: Gözne / Mersin

Ürünün sahibi: Vehibe Şahin (1945)

Ürünü dokuyan kişi: Nimet Sarı (Merhume)

Gözlemin yapıldığı tarih: 23.08.2018

Ürünün dokunduğu tarih: 1977

Oluşturulan ürün-eşya: Un çuvalı

Ürünün boyutları: $68 \times 118 \mathrm{~cm}$

Kullanılan iplik türleri: Çözün - Argaç: Kı1, pamuk karışımı, Nakış: Orlon

Kullanılan renkler: Siyah, beyaz, kırmızı, yeşil

Ürüne verilen genel ad: Çuval

Dokumada kullanılan desenleme tekniği: Cicim teknikli

Kullanılan motif isimleri: Pıtrak, çengelli su

Kompozisyon özellikleri: Ön ve arka yüzün yekpare dokunduğu un çuvalı ortadan ikiye katlanıp yanlardan dikilmiştir. Yan yana yedi, üst üste sekiz sıra şeklinde tasarlanan ön yüzde toplam elli altı pıtrak motifi kullanılmıştır. Kırmızı ve yeşil renklerin almaşı biçimde basit sıralı düzendeki yerleşmesiyle, dokuz gözlü pıtraklar, her sırada çengelli sularla gruplandırılarak yatay kompozisyonlu görünüm kazanmıştır. Un çuvalının arka yüzüneyse bezayağı şeklindeki düz dokuma tekniği uygulanmıştır. 


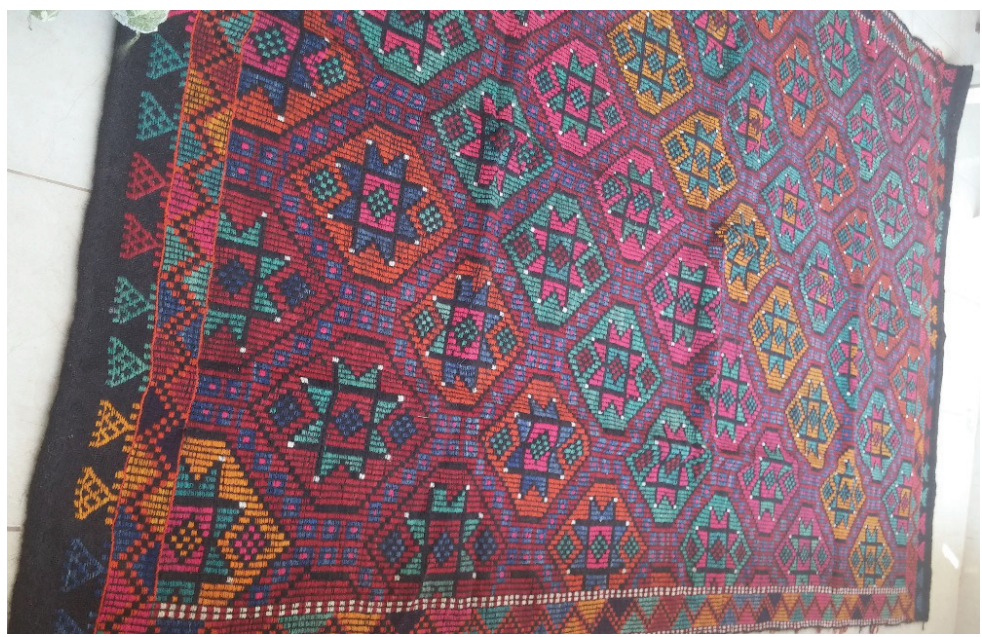

G. 16.Çul yaygı örneği (Emine Tonus, 2018)

Gözlemin yapıldığı yer: Gözne / Mersin

Ürünün sahibi: Vehibe Şahin (1945)

Ürünü dokuyan kişi: Vehibe Şahin, Şirin Taşkın, Ayşe Taşkın

Gözlemin yapıldığı tarih: 23.08 .2018

Ürünün dokunduğu tarih: 1982

Oluşturulan ürün-eşya: Çul yaygı

Ürünün boyutları: 199 x $315 \mathrm{~cm}$

Kullanılan iplik türleri: Çözün - argaç: Kı1, Nakış: Yün

Kullanılan renkler: Lacivert, pembe, kınalı sarı, cengari yeşil, siyah, çatkı sarısı, beyaz, kırmızı

Ürüne verilen genel ad: Çul yaygı

Dokumada kullanılan desenleme tekniği: Zili teknikli

Kullanılan motif isimleri: Çıngıllı zili (Yıldız), küpe, eğri su, bereket, altıgen, göz

Kompozisyon özellikleri: On iki çileyle dokunan ürün, üç kişi tarafindan on günde tamamlanmıştır. Kısa kenarlarda iki, uzun kenarlarda bir adet ayakla çerçeve içine alınan dokuma, yörede "çıngıllı zili" ismiyle bilinen motifin almaşık düzende tekrarlanmasından meydana gelmiştir. Yarım motifle başlayan zemin yine yarım motifle bitirilmiştir. "Çıngıl”, yörede yıldız kollarına verilen isimdir. Bu motif dikey eksende birer adet bereket sembolüyle tamamlanmıştır. Çerçevesi göz motifiyle kuvvetlendirilen "çıngıllı zili"ye, altıgen etrafına uygulanan renkten ötürü "kırmızı çatkılı" denilmiştir. Dokumanın dört bir tarafı eğri suyla çevrilirken, kısa kenarlarda ayrıca küpe motifleri de kullanılmıştır. 


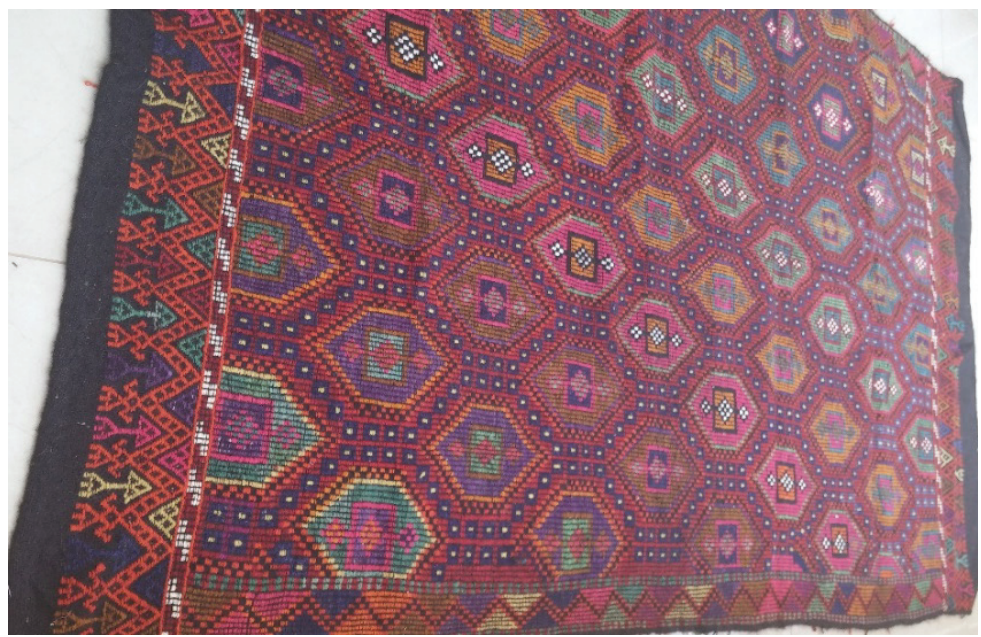

G. 17. Çul yaygı örneği (Emine Tonus, 2018)

Gözlemin yapıldığı yer: Gözne / Mersin

Ürünün sahibi: Vehibe Şahin (1945)

Ürünü dokuyan kişi: Vehibe Şahin, Nevin Şahin

Gözlemin yapıldığı tarih: 23.08.2018

Ürünün dokunduğu tarih: 1982

Oluşturulan ürün-eşya: Çul yayg1

Ürünün boyutları: 171 x $271 \mathrm{~cm}$

Kullanılan iplik türleri: Çözün - argaç: Kı1, Nakış: Yün

Kullanılan renkler: Lacivert, pembe, kınalı sarı, cengari yeşil, yeşil, cevizi yeşil, siyah, sar1, beyaz, kirmız1

Ürüne verilen genel ad: Çul yayg1

Dokumada kullanılan desenleme tekniği: Zili teknikli

Kullanılan motif isimleri: Eğri su, küpe, bereket, göz, dörtgen, altıgen, çengel

Kompozisyon özellikleri: Kısa kenarlarda üç, uzun kenarlarda bir adet ayakla çerçeve içine alınan dokuma "tabakalı zili" motifinin almaşık biçimde tekrarlanmasından meydana gelmiştir. Tabakalı zili, altıgen içerisinde, merkezinde bereket sembolü bulunan dörtgen ile dikey eksende ona bağlı biçimde yerleştirilen birer adet göz motifinden yapılmıştır. Çerçevesi göz motifiyle kuvvetlendirilen altıgenler, etrafına uygulanan renkten ötürü "kırmızı çatkılı” ismiyle bilinmektedir. Yarım motifle başlayıp, yine yarım motifle bitirilen dokumanın dört bir tarafı eğri suyla çevrilirken, kısa kenarlarda ayrıca küpe ve çengelli su motifleri de kullanılmıştır. 


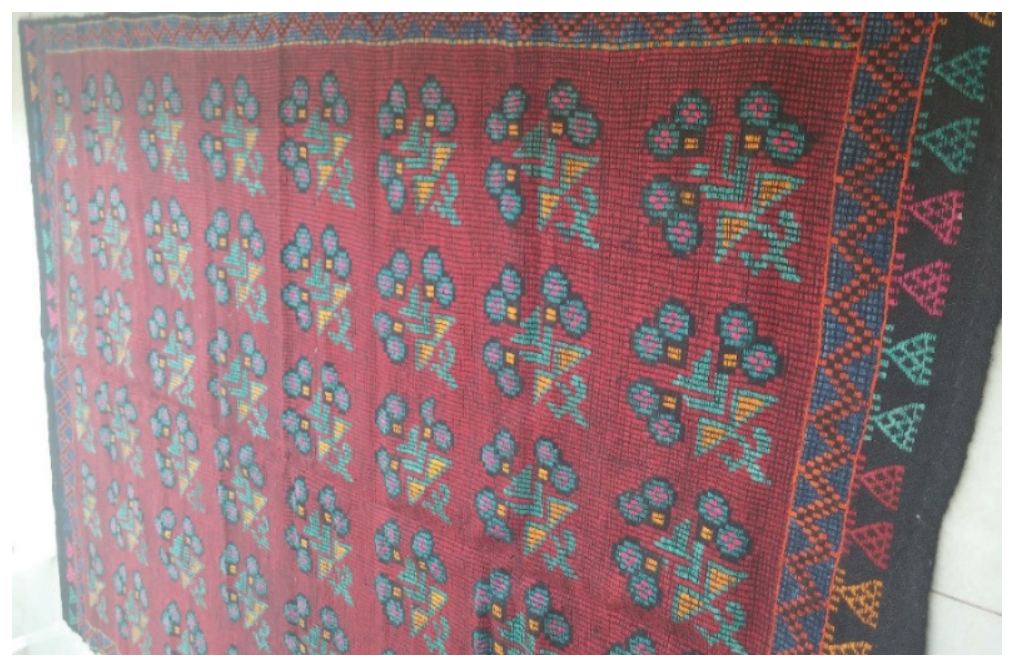

G. 18. Çul yaygı örneği (Emine Tonus, 2018)

Gözlemin yapıldığı yer: Gözne / Mersin

Ürünün sahibi: Vehibe Şahin (1945)

Ürünü dokuyan kişi: Vehibe Şahin, Nevin Şahin

Gözlemin yapıldığı tarih: 23.08 .2018

Ürünün dokunduğu tarih: 1982

Oluşturulan ürün-eşya: Çul yaygı

Ürünün boyutları: 200 x $316 \mathrm{~cm}$

Kullanılan iplik türleri: Çözün - argaç: Kı1, Nakış: Yün

Kullanılan renkler: Lacivert, pembe, kınalı sarı, cengari yeşil, siyah, çatkı sarısı, kırmız1

Ürüne verilen genel ad: Çul yayg1

Dokumada kullanılan desenleme tekniği: Zili teknikli

Kullanılan motif isimleri: Gül, yaprak, dal uzantısı, eğri su, küpe

Kompozisyon özellikleri: Yatay ve dikey kompozisyonlu biçimde tasarlanan dokuma, eğri su motifiyle çerçeve içine alınırken, kısa kenarlarda ayrıca küpe motifi de kullanılmıştır. Dal uzantısı, yaprak ve gülün basit sıralı diziliminden meydana gelen zemin, sonsuzluk prensibine göre planlanmıştır. 


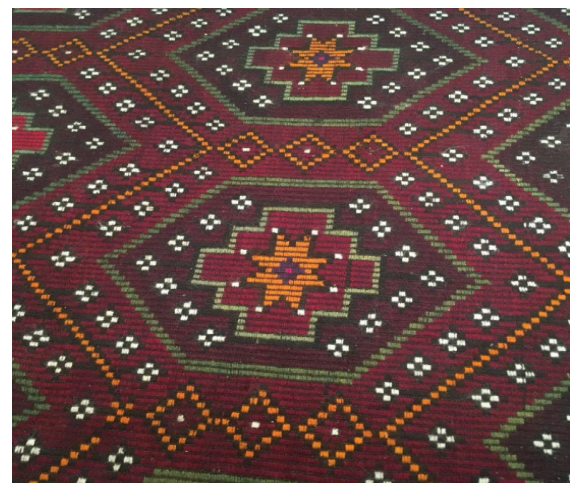

G. 19. Çul yayg1 örneği (Meryem Tömen, 2018)

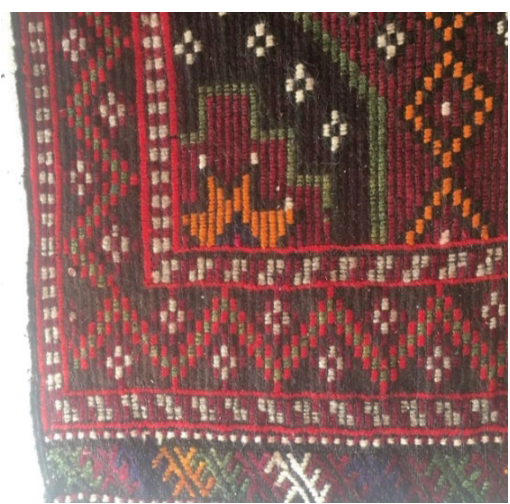

G. 20. Çul yaygıdan kenar detayı (Meryem Tömen, 2018)

Gözlemin yapıldığı yer: Gözne / Mersin

Ürünün sahibi: Şadiye Hanım

Ürünü dokuyan kişi: Bilinmiyor

Gözlemin yapıldığı tarih: 22.08.2018

Ürünün dokunduğu tarih: Bilinmiyor

Oluşturulan ürün-eşya: Çul yayg1

Ürünün boyutları: 180 x $240 \mathrm{~cm}$

Kullanılan iplik türleri: Çözün- Argaç: Kı1, Nakış: Yün

Kullanılan renkler: Kırmızı, beyaz, kahverengi, kınalı sarı, bordo, mor, yeşil

Ürüne verilen genel ad: Çul yayg1

Dokumada kullanılan desenleme tekniği: Zili teknikli

Kullanılan motif isimleri:Yıldız, çiçek, göz, altıgen, eğri su, elti eltiye küstü, ala boncuk Kompozisyon özellikleri: Kısa kenarlarda dar ve geniş ayak kullanılan dokuma, uzun kenarlarda sadece geniş ayakla çerçeve içine alınmıştır. Yatay ve dikey eksende ala boncukla bezeli kenar suyuysa geniş ayağı boydan boya çevrelemektedir. Başlangıç ve bitiş dar ayakları elti eltiye küstü motifiyle bezenirken, geniş ayaklarda çiçekli eğri su kullanılmıştır. 


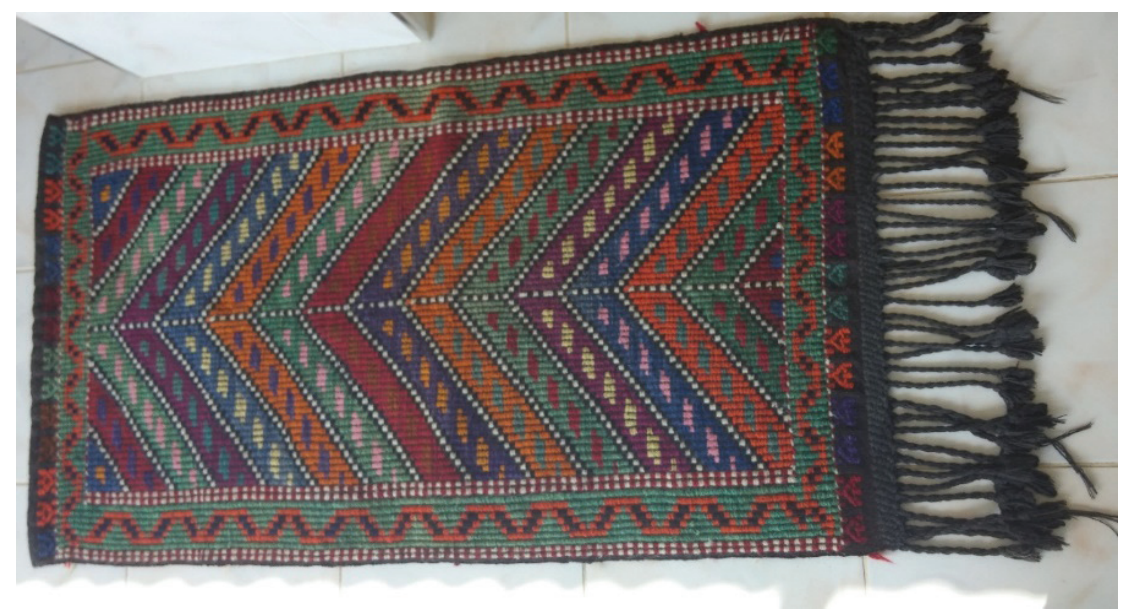

G. 21. Çul seccâde örneği (Emine Tonus, 2018)

Gözlemin yapıldığı yer: Gözne / Mersin

Ürünün sahibi: Şirin Taşkın (1943)

Ürünü dokuyan kişi: Şirin Taşkın

Gözlemin yapıldığı tarih: 14.09.2018

Ürünün dokunduğu tarih: 1975

Oluşturulan ürün-eşya: Namazla (Namazlağı)

Ürünün boyutları: 68 x $117 \mathrm{~cm}$.

Kullanılan iplik türleri: Çözün- Argaç- Nakış: Yün

Kullanılan renkler: Yeşil, kınalı sarı, lacivert, beyaz, vişne rengi, sarı, kırmızı, siyah, pembe

Ürüne verilen genel ad: Namazla

Dokumada kullanılan desenleme tekniği: Zili teknikli

Kullanılan motif isimleri: Ala boncuk, eğri su, küpe, çatkı

Kompozisyon özellikleri: Dikey eksende $1 / 2$ simetriyle dokunan seccâde, eğri su motifiyle bezenmiş bir adet ayak tarafından çerçeve içine alınmıştır. Ayak ise uzun kenarlarda ala boncukla sınırları kuvvetlendirilmiştir. $16 \mathrm{~cm}$. uzunluğundaki saçak örülmüş ve uçları püskü şeklinde bırakılmıştır. Saçaktan sonra siyah zemin üzerine farklı renklerdeki küpe motifleri, seccâde bitişinde de kullanılmıştır. Seccâdenin dikey yönlü hak orta noktası beyaz çatkıyla ikiye bölünmüş, her iki tarafa simetrik ve verev biçimde yerleştirilen beyaz çatkılarla da desene balıksırtı görünümü kazandırılmıştır. 


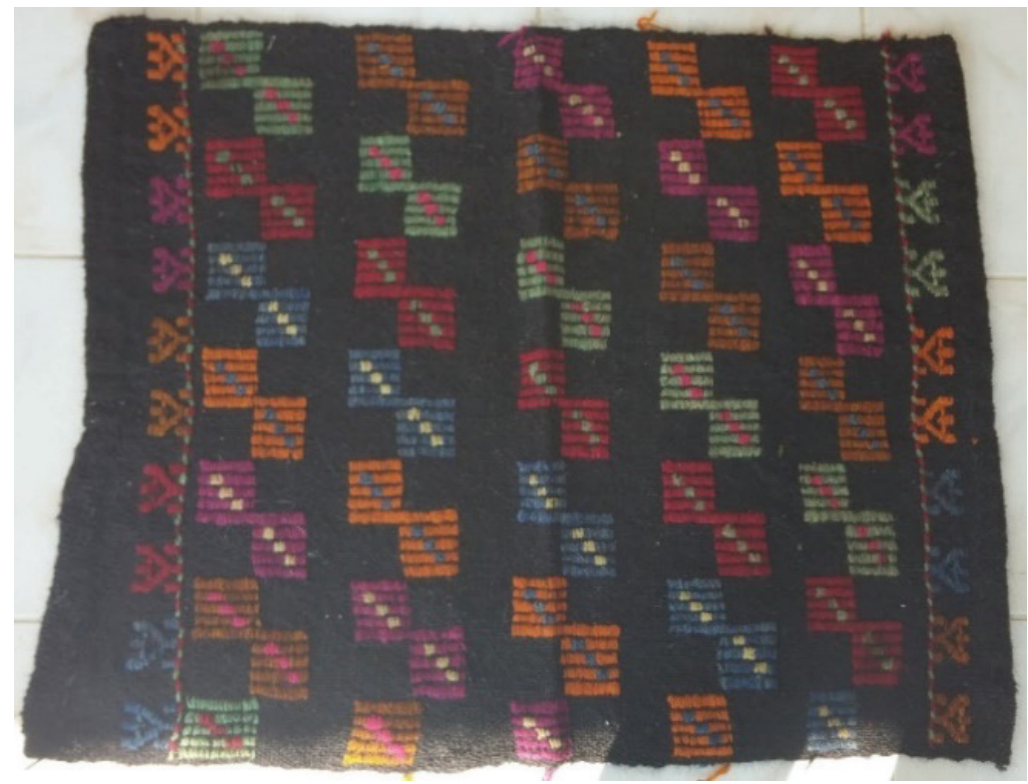

G. 22. Köşe çaputu örneği (Emine Tonus, 2018)

Gözlemin yapıldığı yer: Gözne / Mersin

Ürünün sahibi: Şirin Taşkın (1943)

Ürünü dokuyan kişi: Şirin Taşkın

Gözlemin yapıldığı tarih: 14.09.2018

Ürünün dokunduğu tarih: 1970

Oluşturulan ürün-eşya: Köşe çaputu

Ürünün boyutları: 70 x $87 \mathrm{~cm}$

Kullanılan iplik türleri: Çözün- Argaç: Keçi kıl1, Nakış: Yün

Kullanılan renkler: Yeşil, kırmızı, mavi, çatkı sarısı, vişne, cevizi yeşil, pembe, siyah Ürüne verilen genel ad: Köşe çaputu

Dokumada kullanılan desenleme tekniği: Zili ve cicim teknikli

Kullanılan motif isimleri: Küpe, yarım satranç

Kompozisyon özellikleri: Dokuma yönüne göre, yatay eksende başlangıç ve bitişler küpe motifiyle sınırlandırılırken, dikey eksen sonsuza uzanırcasına serbest bırakılmıştır. Zemin ise farklı renklerdeki yarım satranç motiflerinin yine verev biçimde diziliminden meydana gelmiştir. 


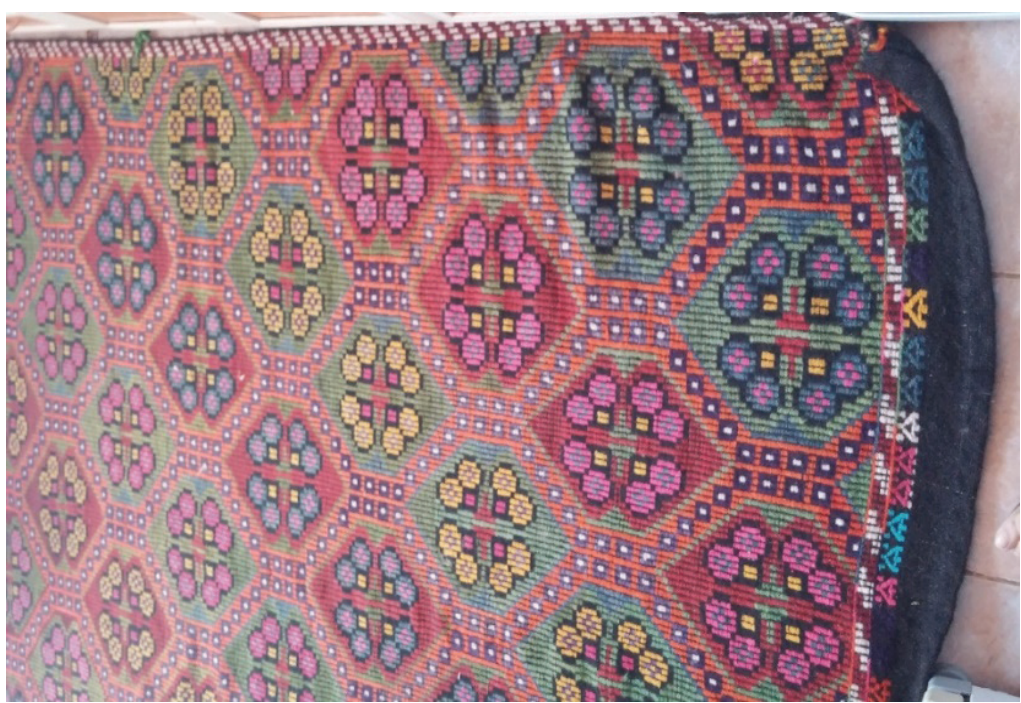

G. 23. Çul yaygı örneği (Emine Tonus, 2018)

Gözlemin yapıldığı yer: Gözne / Mersin

Ürünün sahibi: Ayşe Aksoy (1965)

Ürünü dokuyan kişi: Ayşe Turgut (Merhume)

Gözlemin yapıldığı tarih: 14.09.2018

Ürünün dokunduğu tarih: 1975

Oluşturulan ürün-eşya: Çul yayg1

Ürünün boyutları: 187 x $300 \mathrm{~cm}$

Kullanılan iplik türleri: Çözün- Argaç- Nakış: Yün

Kullanılan renkler: Siyah, sarı, mavi, beyaz, pembe, yeşil, mor, kırmızı, kınalı sarı

Ürüne verilen genel ad: Çul yaygı

Dokumada kullanılan desenleme tekniği: Zili ve cicim teknikli

Kullanılan motif isimleri: Küpe, çengel, gül, göz, çatk1

Kompozisyon özellikleri: Siyah düz dokumayla başlanan çulun başlangıç ve bitişlerinde küpe motifleri kullanılmıştır. Kırmızı zemin üzerine beyaz rengin uygulandığ çengel motifli dar ayak, dokumayı çerçeve içine almıştır. Sonsuzluk prensibine uygun şekilde tasarlanan zeminde girift şekilde yerleştirilen altıgenler dikkat çekmektedir. Altıgenler arasındaki çatkılar göz motifiyle doldurulmuş ve bu motifle nazardan korunmak amaçlanmıştır. Gül motifiyle bezeli olan altıgenler, iç dolgularında kullanılan renklerle verev bir görünüm almışlardır. 


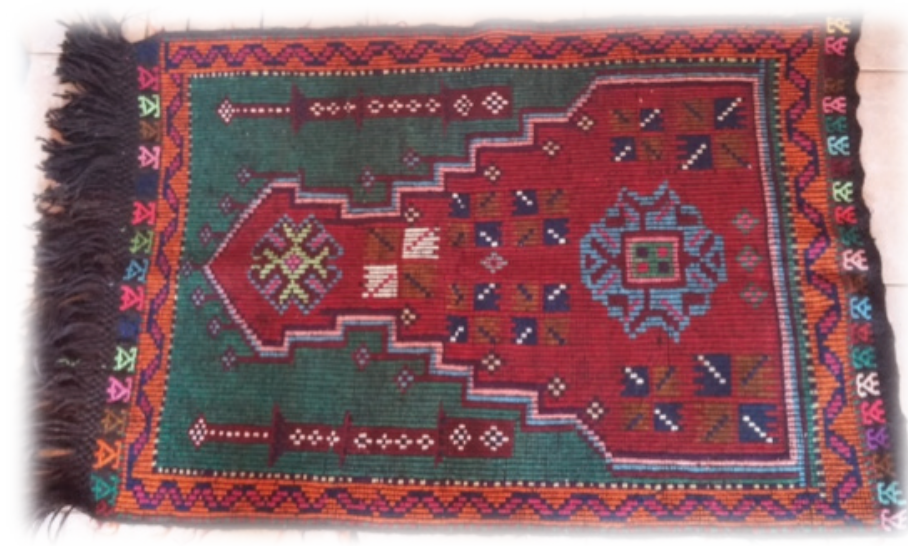

G. 24. Çul seccâde örneği (Emine Tonus, 2018)

Gözlemin yapıldığı yer: Gözne / Mersin

Ürünün sahibi: Ayşe Aksoy (1965)

Ürünü dokuyan kişi: Ayşe Turgut (Merhume)

Gözlemin yapıldığı tarih: 14.09.2018

Ürünün dokunduğu tarih: Bilinmiyor

Oluşturulan ürün-eşya: Seccâde

Hangi amaçla yapıldığı: Aile bireylerinin kullanımı

Ürünün boyutları: 72 x $115 \mathrm{~cm}$

Kullanılan iplik türleri: Çözün- Argaç- Nakış: Yün

Kullanılan renkler: Siyah, cengari yeşil, kınalı sarı, kahverengi, pembe, yeşil, lacivert, mavi, bordo, mor

Ürüne verilen genel ad: Namazla

Dokumada kullanılan desenleme tekniği: Zili ve cicim teknikli

Kullanılan motif isimleri: Küpe, eğri su, minare, çiçek, pıtrak, göz, çınar yaprakları

Kompozisyon özellikleri: Dikey eksende $1 / 2$ simetrik kompozisyonla tasarlanan seccâdede boğumlu mihrap biçimi uygulanmıştır. Başlangıç ve bitişler yine küpe motifiyle bezenirken, eğri su dokumayı çerçeve içine alınmıştır. Mihrap kemeri boğum noktasına kadar basamaklar şeklinde daralmış ve boğum noktasından itibaren de yine basamaklar şeklinde genişlemiştir. Konturlarında kullanılan çıngıllı çiçek motifleri zemin boşluklarını doldurur niteliktedir. Mihrap nişinin iç kısmında nazarlardan korunma ve bereket anlamlarında değerlendirilen iki adet pıtrak motifi seccâdenin ana temasını vurgulamıştır. Ayrıca, iki rengin karşılıklı kullanımından meydana gelen dört adet çınar yaprağıyla göz motiflerinin serbest dağılımı zemin boşluklarını doldurmak için kullanılmıştır. Mihrap nişinin dış boşluklarında karşılıklı simetrik biçimde yerleştirilen ve iç dolgusunda göz motiflerinin uygulandığı iki adet minare figürü görülmektedir. 


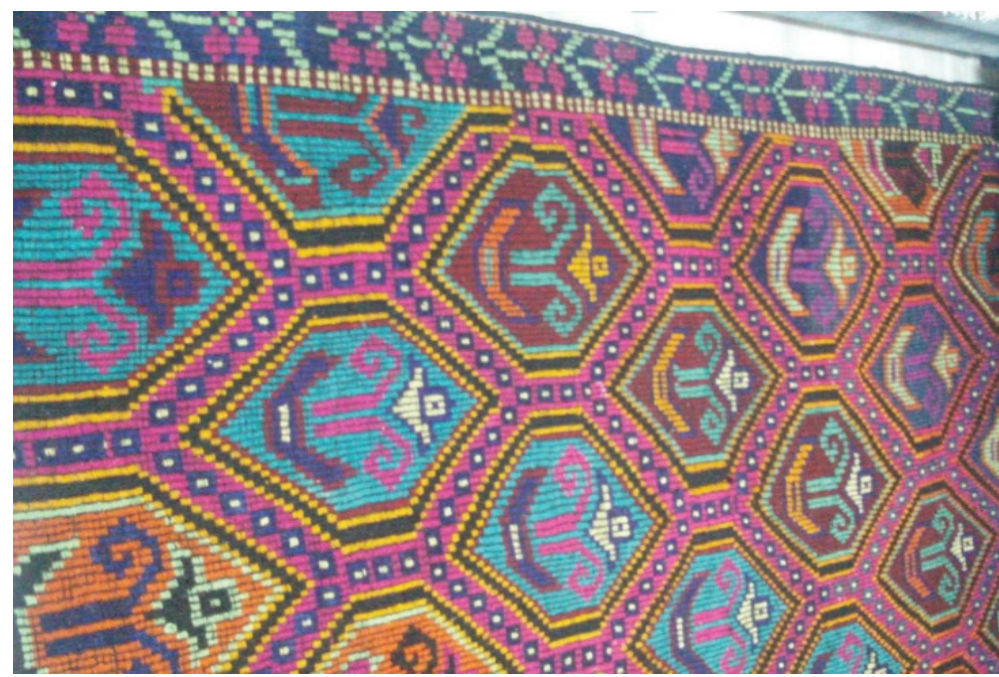

G. 25. Çul yaygı örneği (Emine Tonus, 2018)

Gözlemin yapıldığı yer: Gözne / Mersin

Ürünün sahibi: Mihri Akın (Merhume)

Ürünü dokuyan kişi: Bilinmiyor

Gözlemin yapıldığı tarih: 14.09.2018

Ürünün dokunduğu tarih: Bilinmiyor

Oluşturulan ürün-eşya: Çul yaygı

Ürünün boyutları: 170 x $270 \mathrm{~cm}$

Kullanılan iplik türleri: Çözün- Argaç- Nakış: Yün

Kullanılan renkler: Siyah, çatkı sarısı, bordo, pembe, lacivert, mavi, kınalı sarı, beyaz,

Ürüne verilen genel ad: Çul yayg1

Dokumada kullanılan desenleme tekniği: Zili teknikli

Kullanılan motif isimleri: Gül, lale, yaprak, göz, altıgen, ala boncuk

Kompozisyon özellikleri: Sonsuzluk prensibine uygun tasarlanan ve bir adet geniş ayakla çerçeve içine alınan zemine girift şekilde yerleştirilen altıgenler dikkat çekmektedir. Altıgenler arasındaki çatkılar göz motifiyle doldurulmuş ve nazardan korunmak amaçlanmıştır. Lâle motifiyle bezeli olan altıgenler, iç dolgularında kullanılan renklerle verev bir görünüm almışlardır. Zemin ile ayak bölümü dikey eksende ala boncuk motifleriyle sınırları belirlenmiştir. Ayak, gül ve yaprak motiflerinin ötelemeli yerleşiminden meydana gelmiştir. Siyah düz dokuma ile başlanan çulun başlangıç ve bitişlerinde küpe motifleri kullanılmıştır. Kırmızı zemin üzerine beyaz rengin uygulandığı çengel motifli dar ayak, dokumayı çerçeve içine almıştır. 


\section{Sonuç}

Geçmişi uzun yıllar öncesine dayanan 1star dokumacılığı, günümüzde Mersin ili sınırları içerisinde yer alan Gözne Yaylası'nda devamlılığg sağlanamayan sanatlar arasındadır. Çul ismiyle de bilinen bu dokumalar, orta yaş insanların günlük kullanımlarında tercih ettikleri ürünlerdendir. Nesilden nesile el değiştiren bu ürünler, günümüzde çeyizlik eşyalar arasındaki yerini korumaktadır. Ancak yeni neslin dokumaya ilgi duymaması ve dokuyucu nüfusunun yaşlanması nedeniyle yeni üretimler yapilamamaktadir.

Yapılan araştırmada, çul yaygı, köşe çaputu, seccâde, heybe, un ve bulgur çuvalı şeklinde yirmi farklı ürün incelenmiştir. Cicim, zili ve düz dokuma tekniklerinin kullanıldığı bu dokumalar, satranç, köşşek tabanı, tabakalı zili, güllü, dilikli zili ve çıngıllı zili gibi yöresel isimleriyle bilinen motifler yanında pitrak, eğri su, küpe, elibelinde, sığır sidiği, yıldız, bereket, ala boncuk, göz, elti eltiye küstü, çengel, gül ve lâle gibi tamamlayıcı motiflerle de bezenmiştir. Geçmişte doğal boyalı olan bu dokumalar, son yıllarda hazır boyalı yün, kıl, kıllama (yün ve pamuk karışımı), orlon ve tırlık (pamuk) ile yapılmıştır. Gözne dokumalarında beyaz, siyah, gri, mavi, kırmızı, yeşil, cevizi yeşil, cengari yeşil, sarı, kınalı sarı, turuncu, mor, pembe ve lacivert tercih edilen renklerdir. Ticari bir amaçtan çok, aile bireylerinin günlük hayatta kullanımı ve çeyizlik amacıyla dokunan bu ürünlerde motifler, basit sıralı, verev, aynı motifin almaşık dizilimi, eşkenar dörtgen bölümlemeli, yatay ve dikey kompozisyonlu olmak üzere beş farklı biçimde yapılmıştır.

Gözne, tarım ve hayvancılığa elverişli iklim ve bitki örtüsüyle dokumacılık açısından oldukça uygun bir yerdir. Ancak, modern hayatın cazibesi yöre insanlarını geleneksel değerlerden uzaklaştırmada başlıca etken sayılmakla birlikte, el dokumacılığının gelir getirici meslek görünümünden çıkması, pazarlama sorunu, yoğun emek, zaman ve sabır gerektirmesi bu ve benzeri sanatlara ilgiyi azaltııştır.

Kültür varlıklarının korunması kapsamında, ata sanatı kabul edilen 1star vb. dokumaların, kamu kurumları ya da özel sektörlerce desteklenmesi gerekmektedir. Bir kültürü yaşatma bilinciyle açılacak kurs ya da hobi merkezleriyle dokunmuş ürünlere sağlanacak pazar imkânı, yöre halkının bu sanatı yaşatmak istemesinde önemli rol oynayacağı düşünülmektedir. 


\section{Kaynakça/References}

Deniz, Bekir. Türk Dünyasında Halı ve Düz Dokuma Yaygıları. Ankara: Atatürk Kültür Merkezi Yayını, 2000.

Develi, H. Şinasi. Dünden Bugüne Mersin. Mersin: Mersin Büyükşehir Belediye Yayınları, 2008.

Diler, Ahmet ve Marc-Antoine Gallice. Kilimin Sembolleri. İstanbul: Alfa Basım Yayım Dağıtım Ltd. Şti., 2018.

“Gözne harita KGM.” Erişim 25.04.2019.

https://www.kgm.gov.tr/SiteCollectionImages/KGMimages/Haritalar/b5.jpg.

Kaynar, Hülya ve Emine Tonus. "Kangal Yöresine Ait Bir Grup Anadolu Halısının Teknik ve Desen Analizi.” Art-Sanat 10 (Ocak 2018): 233. Erişim 29.12.2019. http://doi.org/10.26650/artsanat.2018.10.0009

“Namazlığı.” Güncel Türkçe Sözlük. Erişim 25.01.2020. https://sozluk.gov.tr

Türk El Dokuması Halılar. Ankara: T.C. Kültür ve Turizm Bakanlığı, Döner Sermaye İşletmesi Merkez Müdürlüğü Yayını, t.y.

\section{Kaynak kişiler}

Ayşe Hanım (1946) Ev Hanımı

Ayşe Aksoy (1965) Ev Hanımı

Meryem Tömen (1965) Ev Hanımı

Nevin Şahin (1966) Ev Hanımı

Şirin Taşkın (1943) Ev Hanımı

Vehibe Şahin (1945) Ev Hanımı 
